\title{
Analisa Data Foto Udara untuk DEM dengan Metode TIN, IDW, dan Kriging
}

Juwita Arfaini, Hepi Hapsari Handayani

Jurusan Teknik Geomatika, Fakultas Teknik Sipil dan Perencanaan

Institut Teknologi Sepuluh Nopember (ITS)

Jl. Arief Rahman Hakim, Surabaya 60111 Indonesia

email: hapsari@geodesy.its.ac.id

\begin{abstract}
Abstrak- Digital Elevation Model (DEM) atau Model Ketinggian Dijital merupakan suatu model yang merepresentasikan topografi suatu permukaan. Salah satu sumber data yang digunakan untuk membuat model ketinggian dijital ini adalah menggunakan sebaran titik-titik yang memuat informasi koordinat tiga dimensi yaitu $x, y$, dan $z$ di permukaan bumi. Pengambilan data sebaran titik ini dapat dilakukan melalui foto udara stereo yaitu foto udara yang saling bertampalan sehingga memberikan efek tiga dimensi yang kemudian dapat diambil informasinya. Proses yang dilakukan untuk membuat sebaran titik ini kemudian disebut stereoplotting yaitu ekstraksi data secara stereoskopis. Sebaran titik-titik yang kemudian disebut dengan mass point ini kemudian diinterpolasi menggunakan metode TIN, IDW, dan Kriging sehingga dapat diketahui perbedaan model DEM dari masing-masing metode yang diproses menggunakan sumber data yang sama. Dari hasil interpolasi tersebut selanjutnya dilakukan analisa hasil dari elevasi setelah dilakukan interpolasi sehingga diketahui presentasenya. Metode TIN dan IDW memiliki kemiripan dengan memberikan presentasi yang hampir sama pada tiap-tiap kelas ketinggian, sedangkan metode Kriging lebih menampilkan hasil korelasi dari titik-titik dengan radius tertentu sehingga permukaannya tidak ada yang terlalu tinggi ataupun terlalu rendah. Elevasi terkecil dan terbesar terdapat pada metode TIN yaitu sebesar 58,674 meter dan 107, 638 meter. Sementara itu, presentase persebaran ketinggian diklasifikasikan dalam 11 kelas dengan masing-masing intervalnya 5 meter. Persebaran terbesar terdapat pada range 72 - 77 meter. Dari hasil pembuatan DEM kemudian dibuat RMSE nya dengan membandingkan antara elevasi pada metode TIN, IDW, dan Kriging dengan DEM dari TerraSAR-X. Nilai yang memenuhi standar perhitungan RMSE adalah TIN dan IDW karena kurang dari sama dengan 1 meter sesuai standar RMSE dari ASPRS. Pembuatan DEM paling baik adalah menggunakan metode TIN karena memiliki RMSE terkecil yaitu 0,477 meter.
\end{abstract}

Kata Kunci-DEM, Foto Udara, TIN, IDW, Kriging.

\section{PENDAHULUAN}

$D$ GITAL Elevation Model (DEM) adalah model dijital yang memberikan informasi bentuk permukaan (topografi) dalam bentuk data raster, vektor atau bentuk data lainnya [3]. DEM memuat informasi ketinggian dan kemiringan yang mempermudah interpretasi [1]. sehingga dapat digunakan dalam berbagai aspek kehidupan. Dalam bidang kebencanaan DEM dapat digunakan untuk membuat peta rawan bencana banjir atau tanah longsor. Dalam bidang manajemen sumberdaya DEM dapat digunakan untuk mendapatkan lokasi penambangan. Dan masih banyak kegunaan lainnya dari DEM.

Salah satu sumber data untuk pembentukan DEM adalah foto udara. Foto udara yang dapat digunakan merupakan foto udara stereo atau foto udara yang bertampalan kanan dan kiri. Hal ini dimaksudkan agar didapatkan tidak hanya data $\mathrm{X}$ atau $\mathrm{Y}$ namun juga $\mathrm{Z}$ yang merepresentasikan ketinggian. Foto udara yang dipakai merupakan foto udara skala besar yaitu 1:10.000. Dalam penelitian ini sumber data yang dipakai merupakan dari foto udara skala besar karena representasi permukaan akan tampak lebih jelas dibandingkan dengan foto udara skala menengah maupun dari citra. Foto udara dengan skala kecil sangat bermanfaat terutama untuk manajemen tata ruang sehingga dengan mengolah informasi DEM dari foto udara skala ini dapat memberikan informasi yang lebih detail mengenai relief permukaan bumi yang dipetakan.

DEM dari foto udara salah satunya dapat diolah dari titik dan garis ketinggian yang diolah menggunakan perangkat lunak Summit Evolution. Titik dan garis ini diperoleh dari persebaran mass point, breaklines, unsur hidrografi, serta transportasi dari suatu data foto udara stereo. Titik dan garis ketinggian inilah yang kemudian disatukan untuk membuat DEM dengan beberapa metode yang ditentukan. Tahapan yang digunakan dalam pembuatan unsur-unsur pembentuk ketinggian adalah stereoplotting. Stereoplotting adalah ekstraksi data dari sumber data berupa data radar menjadi data vektor yang dilakukan dengan cara digitasi 3 dimensi secara stereoskopis [4]. Melalui tahapan ini akan didapati informasi mengenai posisi planimetris serta ketinggiannya sesuai dengan yang ada di lapangan. Plotting pada foto udara skala besar juga akan memberikan informasi yang lebih detail data yang ada di lapangan.

Dari unsur pembentuk ketinggian tersebut selanjutnya dapat dibuat DEM dari wilayah yang dipetakan. Pembuatan DEM ini dapat melalui beberapa metode yaitu TIN, IDW, dan Kriging. Metode-metode tersebut dipilih karena telah banyak digunakan pada berbagai penelitian yang masing-masing memiliki kelebihan dan kekurangannya. TIN hampir sama dengan grid yang merupakan data digital untuk merepresentasikan suatu permukaan, namun TIN merepresentasikan permukaan sebagai suatu kesatuan yang berlanjut tanpa ada segitiga yang saling menampal [9]. IDW atau Inverse Distance Weighted adalah suatu metode yang mensyaratkan kondisi nilai estimasi sebuah titik dipengaruhi oleh titik terdekat yang diketahui dibandingkan titik yang semakin jauh [6]. Sementara metode Kriging mengasumsikan bahwa jarak atau arah antara titik sampel merefleksikan korelasi spasial yang dapat digunakan untuk menjelaskan variasi pada permukaan yang mana hal ini sesuai dengan jumlah spesifik titik-titik maupun keseluruhan titik dengan radius tertentu untuk menentukan hasil nilai untuk tiap-tiap lokasi [5]. 
Permasalahan yang diangkat dari penelitian ini adalah bagaimana perbandingan antara DEM yang dibuat dari metode TIN, IDW, dan Kriging berdasarkan data foto udara yang dipakai. Manfaat yang diharapkan pada penelitian ini adalah dapat mengetahui perbandingan DEM yang dibuat dari metode TIN, IDW, dan Kriging serta mampu untuk memberikan rekomendasi terhadap penelitian selanjutnya yang berkaitan dengan pembuatan DEM.

\section{METODE PENELITIAN}

\section{A. Lokasi Penelitian}

Penelitian dilakukan berdasarkan lokasi foto udara yang dipakai yaitu di Kecamatan Tegineneng, Kabupaten Pesawaran, Provinsi Lampung dengan koordinat pada model foto yang digunakan adalah $5^{\circ} 13^{\prime} 11.01 "$ LS dan $105^{\circ} 8^{\prime} 11.68^{\prime \prime}$ BT hingga $5^{\circ} 13^{\prime} 12.85^{\prime \prime}$ LS dan $105^{\circ}$ 9'29.61" BT.
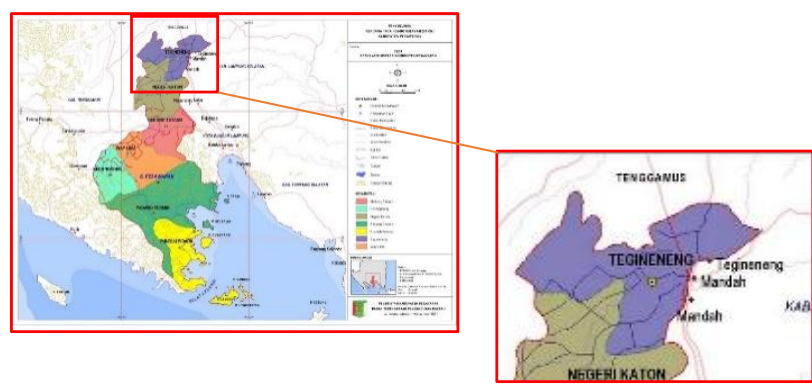

Gambar 1. Lokasi Penelitian

\section{B. Data dan Peralatan}

1) Data

Data yang digunakan dalam penelitian ini adalah:

a. Foto udara kiri dan kanan Kecamatan Tegineneng, Provinsi Lampung. Foto udara yang digunakan dalam format SMTI.

b. Parameter Orientasi Luar (EOP)

c. Parameter Orientasi Dalam (IOP) format *.Cam

d. Data pengukuran GCP format *.CON

e. Data DEM TerraSAR-X wilayah Lampung

2) Peralatan

Peralatan yang digunakan dalam penelitian ini adalah:

a. Komputer workstation dengan spesifikasi minimal setara dengan i7, 64bit, 8GB RAM, 2TB internal harddisk dengan monitor $120 \mathrm{~Hz}$

b. Perangkat lunak DAT/EM Summit Evolution

c. Perangkat lunak AutoCAD Map 3D

d. Perangkat lunak ArcGIS

e. Kacamata 3D

f. Mouse 3D

\section{Diagram Alir Pengolahan Data}

Tahapan pengolahan data yang dilaksanakan dalam penelitian ini adalah sebagai berikut :

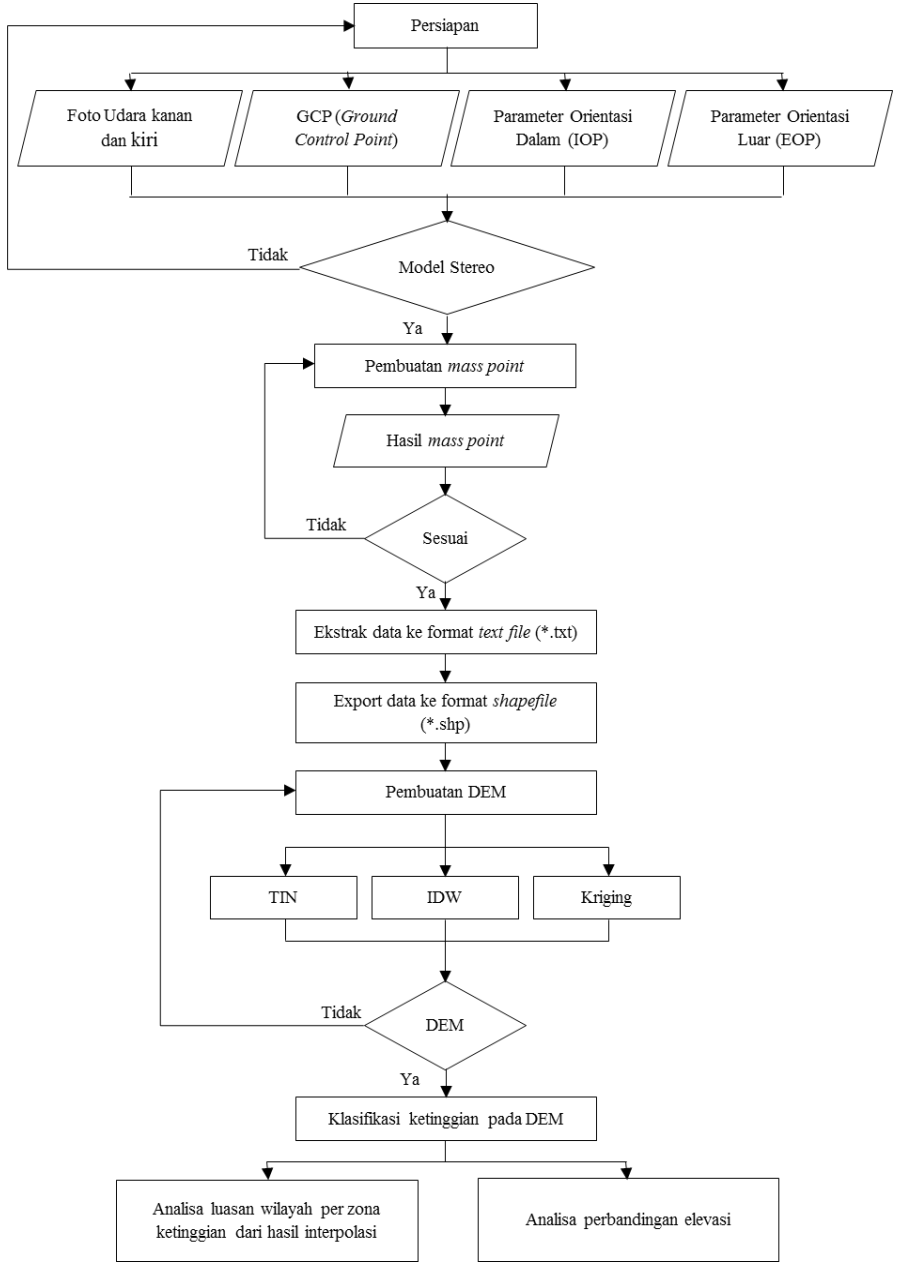

Gambar 2. Diagram alir pengolahan data

Dari diagram alir pengolahan di atas dapat dijelaskan bahwa:

1) Setelah dilakukan pengumpulan data yang dibutuhkan untuk penelitian maka selanjutnya adalah membuat model stereo menggunakan perangkat lunak Summit Evolution. Untuk membuat model stereo dimasukkan parameter orientasi luar berupa X, Y, Z, Phi, Kappa, dan Omega sehingga model stereo memiliki orientasi.

2) Setelah terbentuk model stereo, pembuatan mass point dimulai. Pada proses ini diperlukan mouse dan kacamata 3D yang terintegrasi dengan komputer workstation yang digunakan untuk membuat digitasi yang memiliki informasi baik X, Y, maupun Z. Mass point berguna untuk pembuatan relief permukaan bumi di wilayah yang ditentukan.

3) Jika pembuatan keseluruhan mass point selesai dan sesuai, maka data yang telah ada dikonversi dalam bentuk text file sehingga memudahkan untuk dieksport dalam bentuk shape file nantinya agar data yang ada kemudian dapat diolah untuk mendapatkan DEM. Parameter kesesuaian mass point adalah jika telah sesuai dengan prinsip paralaks yaitu ketika half mark dapat bergeser tidak pada posisinya sampai bergabung menjadi satu sama lain menjadi satu titik yang terlihat pada stereomodel dan terletak pada suatu elevasi. Jika half mark digeser menjadi berdekatan, parallax dari half marks bertambah dan titik yang telah 
menyatu akan lebih terlihat naik, sebaliknya jika half mark tersebut saling dijauhkan, maka parallax berkurang dan titik yang menyatu terlihat semakin ke dalam [6].

4) Selanjutnya adalah pembuatan DEM dengan menggunakan beberapa metode yaitu TIN, IDW, dan Kriging yang keseluruhannya menggunakan perangkat lunak ArcGIS.

5) Tahap terakhir adalah analisa. Analisa pada penelitian yang dilaksanakan berupa analisa luasan wilayah per zona ketinggian dari ketiga metode yang digunakan serta perbandingan antara hasil ketinggian yang didapatkan dari DEM yang dibuat dari ketiga metode tersebut sehingga dapat diketahui perbedaan elevasi yang terjadi setelah dilakukan interpolasi dan dapat disimpulkan manakah yang sesuai untuk digunakan di lokasi penelitian.

\section{HASIL DAN DISKUSI}

\section{A. Hasil Stereoplotting}

Tahapan stereoplotting dilaksanakan secara dijital menggunakan perangkat lunak DAT/EM Summit Evolution. Hasil dari stereoplotting berupa mass point yang memuat informasi koordinat $\mathrm{x}, \mathrm{y}$, dan $\mathrm{z}$.

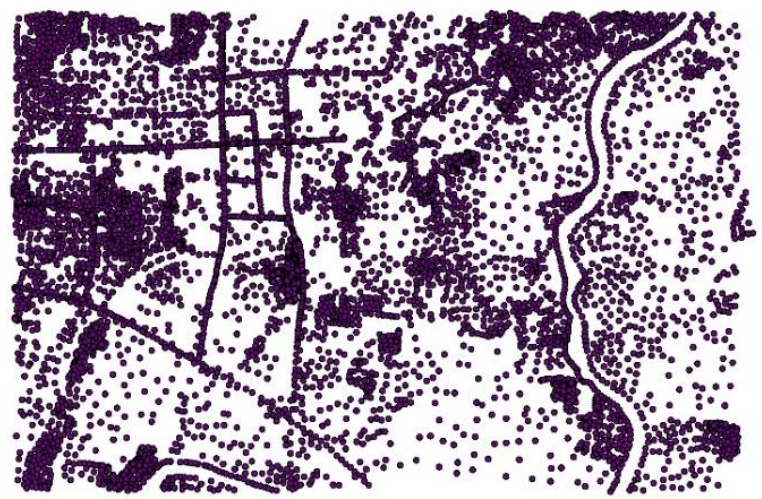

Gambar 3. Hasil pembuatan mass point

\section{B. Hasil Pembuatan DEM}

1) $T I N$

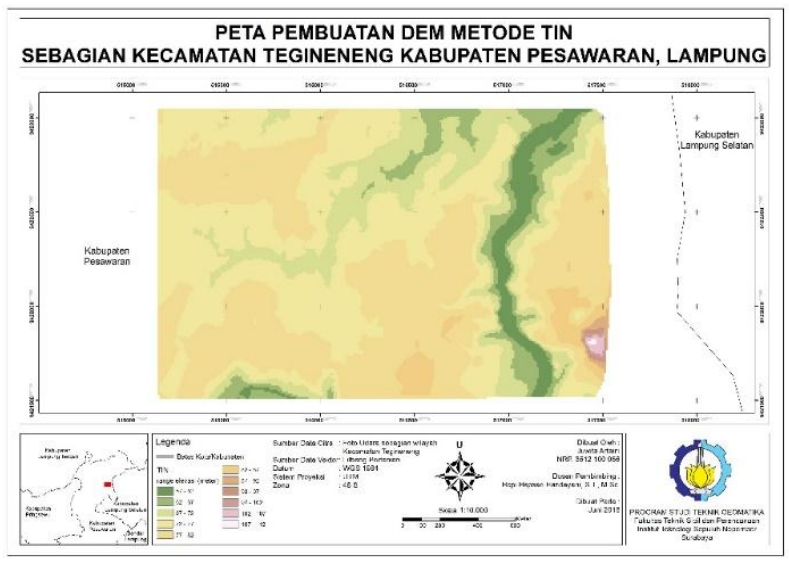

Gambar 4. Hasil interpolasi menggunakan TIN
2) $I D W$

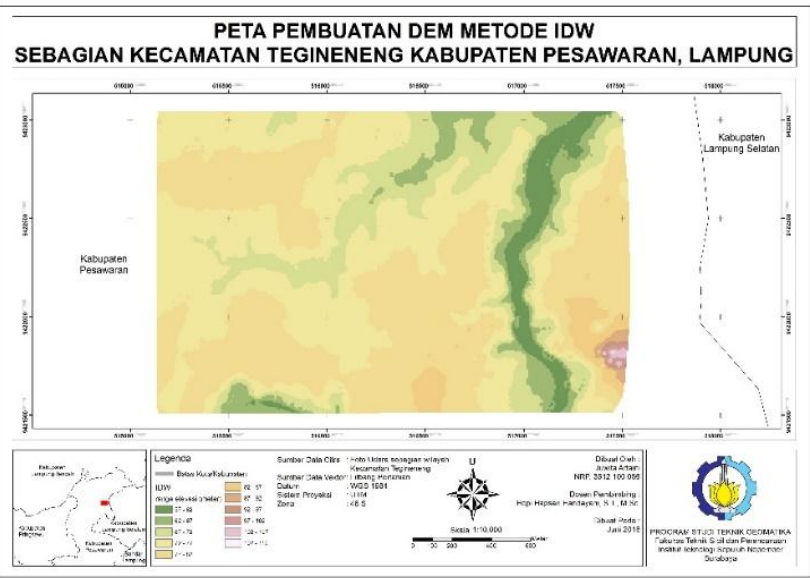

Gambar 5. Hasil interpolasi menggunakan IDW

3) Kriging

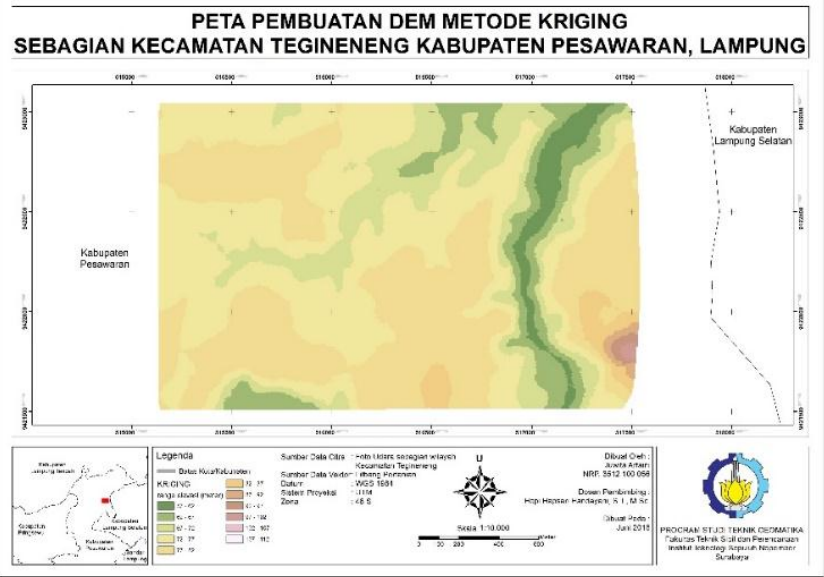

Gambar 6. Hasil interpolasi menggunakan Kriging

\section{Hasil Perbandingan Ketelitian DEM Metode TIN, IDW, dan Kriging dengan TerraSAR-X}

Sampel yang diambil dalam penelitian jumlahnya ada 55 titik yang tersebar secara acak pada wilayah penelitian. Di bawah ini merupakan hasil dari RMSE 55 titik yang digunakan sebagai sampel dalam penelitian. Rumus yang digunakan dalam RMSE [7] :

$$
R M S E=\sqrt{\frac{1}{n} \sum_{i=1}^{n}\left(p_{i}-o_{i}\right)}
$$

Keterangan :

$\mathrm{n}$ : jumlah sampel yang digunakan

$o:$ nilai yang diamati

$\mathrm{p}$ : nilai estimasi

Hasil perbandingan dengan DEM dari TerraSAR-X adalah :

Tabel 1.

Hasil Perhitungan RMSE Pembuata DEM

\begin{tabular}{llll}
\multicolumn{4}{c}{ Hasil Perhitungan RMSE Pembuata DEM } \\
\hline \hline \multirow{2}{*}{ RMSE } & TIN & IDW & Kriging \\
\cline { 2 - 4 } & 0,477 & 0,926 & 3,453 \\
\hline \hline
\end{tabular}

Metode TIN menunjukkan hasil RMSE yang paling kecil yaitu sebesar 0,477 diikuti oleh metode IDW sebesar 0,926 dan metode Kriging 3,453. 


\section{Analisa Stereoplotting}

Pelaksanaan kegiatan stereoplotting dilakukan menggunakan perangkat lunak DAT/EM Summit Evolution. Hasil dari kegiatan ini adalah data vektor berupa titik-titik sebaran ketinggian atau mass point. Digitasi mass point dibuat di seluruh permukaan tanah sehingga diharapkan merepresentasikan informasi suatu lokasi dipermukaan tanah yang memuat informasi $\mathrm{x}, \mathrm{y}$, maupun $\mathrm{z}$ nya.

Digitasi untuk unsur hidrografi, dalam hal ini sungai, dibuat titik-titik di tepi-tepinya. Titik-titik untuk tepian sungai ini dibuat rapat sehingga dapat merepresentasikan adanya gap suatu obyek. Sementara untuk unsur transportasi, dalam hal ini jalan, titik-titiknya dibuat linier mengikuti jalan.

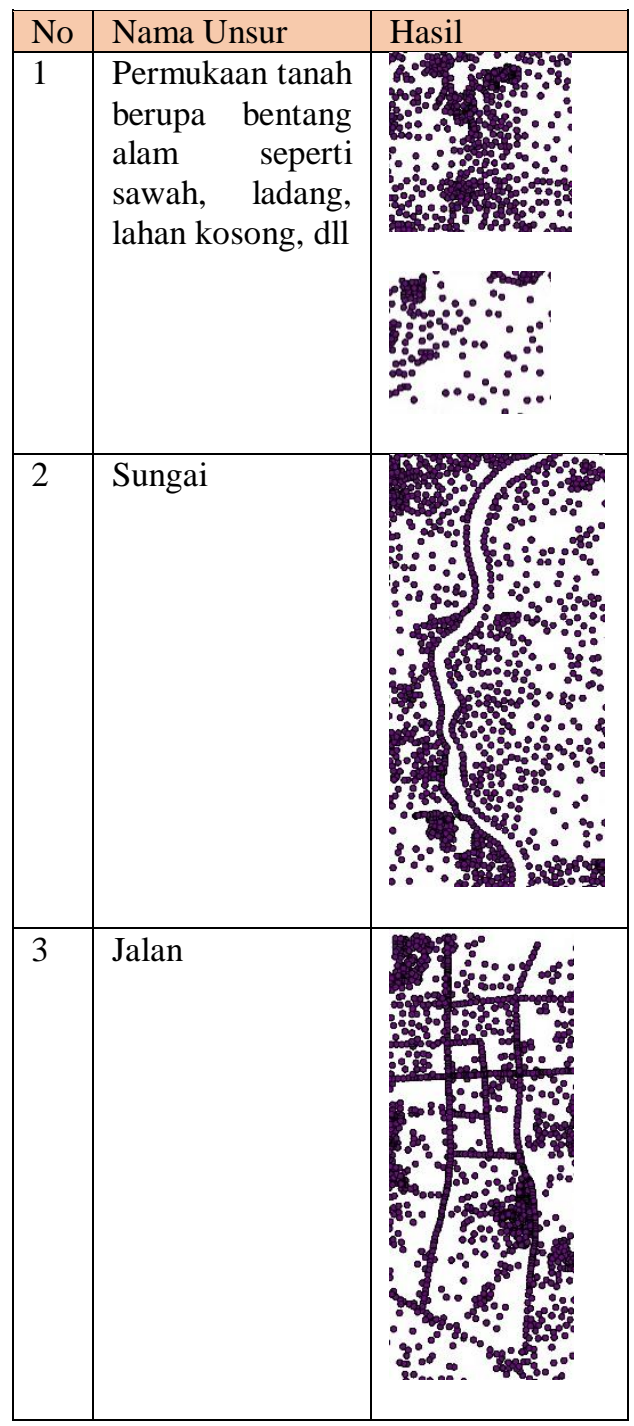

Gambar 7. Hasil pembuatan mass point untuk beberapa unsur

E. Analisa Perbandingan Luasan Wilayah dari Metode Pembuatan DEM

Tabel 2.

Perbandingan luasan hasil pembuatan DEM dari beberapa metode

Range

Kelas

Metode (nilai dalam \%)

\begin{tabular}{ccccc}
\hline \hline & & TIN & IDW & Kriging \\
\hline $57-62$ & 1 & 4,376 & 4,689 & 2,25 \\
$62-67$ & 2 & 9,985 & 9,945 & 12,415 \\
$67-72$ & 3 & 17,385 & 18,017 & 18,71 \\
$72-77$ & 4 & 41,46 & 41,888 & 42,187 \\
$77-82$ & 5 & 24,97 & 23,478 & 22,659 \\
$82-87$ & 6 & 1,385 & 1,526 & 1,306 \\
$87-92$ & 7 & 0,355 & 0,378 & 0,378 \\
$92-97$ & 8 & 0 & 0 & 0,047 \\
$97-102$ & 9 & 0 & 0 & 0,047 \\
$102-107$ & 10 & 0,068 & 0,063 & 0 \\
$107-112$ & 11 & 0,017 & 0,016 & 0 \\
$\Sigma$ & & 100,001 & 100 & 99,999 \\
\hline \hline
\end{tabular}

Presentase diambil dari nilai obyek yang direpresentasikan dalam pixel. Metode TIN memiliki sebaran presentase yang lebih merata di tiap-tiap kelas ketinggian. Dapat dilihat pada Tabel 4.4 bahwa ketinggian dari tiap kelas pada metode TIN tetap ditampilkan hampir seperti data utama yang digunakan. Sedangkan pada metode IDW yang mengambil prinsip jarak antar titik yang mana semakin dekat jarak tersebut akan semakin berpengaruh terhadap elevasi yang dihasilkan menunjukkan hasil yang menyerupai metode TIN.

Pada metode Kriging, menunjukkan hasil yang paling berbeda dibandingkan yang lain. Dengan menggunakan prinsip korelasi antar titik maka nilai dihitung berdasarkan banyaknya titik sekitar yang terikat serta jarak dari tiap-tiap titik tersebut sehingga menampilkan hasil yang berbeda dibandingkan kedua metode sebelumnya yang menampilkan ketiadaan permukaan yang terlalu tinggi maupun terlalu rendah.

Sesuai dengan yang telah dihimpun dari metode TIN, IDW, dan Kriging yang dilakukan dalam penelitian, presentase persebaran ketinggian terbesar terdapat pada range $72-77$ meter diikuti dengan range $77-82$ meter, $62-72$ meter, $62-$ 67 meter, $57-62$ meter, $82-87$ meter, $87-92$ meter dan range lain yang muncul berbeda-beda nilainya pada $92-112$ meter.

Dapat dilihat pada nilai statistik pada Tabel 3 mengenai nilai minimal, maksimal, rata-rata, serta standar deviasi dari ketiga metode yang digunakan.

Tabel 3 .

Nilai statistik dari hasil interpolasi dalam satuan meter

\begin{tabular}{cccc}
\hline Parameter & TIN & IDW & Kriging \\
\hline Min & 58,674 & 58,679 & 59,364 \\
Maks & 107,638 & 107,513 & 99,910 \\
Rata-rata & 74,672 & 74,681 & 74,614 \\
Standar Deviasi & 5,734 & 5,769 & 5,600 \\
\hline \hline
\end{tabular}

Dari nilai tersebut dapat dijelaskan bahwa elevasi terkecil terdapat pada metode TIN yaitu sebesar 58,674 diikuti oleh hasil dari metode IDW sebesar 58,679 dan metode Kriging sebesar 59,364 sedangkan elevasi terbesar terdapat pada hasil dari metode TIN sebesar 107, 638 diikuti metode IDW sebesar 107,513 dan metode Kriging yaitu 99,910. Untuk nilai rata-rata 
dari hasil elevasi setelah dilakukan interpolasi terbesar yaitu 74,681 pada metode IDW dan yang terkecil yaitu 74,614 pada metode Kriging. Sedangkan standar deviasi terbesar terdapat pada metode TIN yaitu 5,734 dan yang terkecil pada metode IDW yaitu 5,600. Hasil pebandingan nilai maksimal dan nilai minimal dari

\section{F. Analisa Ketelitian DEM}

Sesuai dengan hasil yang ditunjukkan pada RMSE yang menyebutkan bahwa metode TIN menunjukkan hasil RMSE yang paling kecil yaitu sebesar 0,477 diikuti oleh metode IDW sebesar 0,926 dan metode Kriging 3,453. Perhitungan selisih elevasi untuk Toleransi untuk RMSE diambil dari akurasi vertikal untuk data elevasi digital hasil penelitian ASPRS Photogrammetric Applications Division (PAD) and Primary Data Acquisition Divisions (PDAD) tahun 2011. Akurasi vertikalnya ditunjukkan dalam tabel berikut ini :

\begin{tabular}{|c|c|c|c|c|c|}
\hline $\begin{array}{c}\text { Vertical } \\
\text { Data } \\
\text { Accuracy } \\
\text { Class }\end{array}$ & $\begin{array}{l}\text { RMSEz } \\
\text { in Non- } \\
\text { Vegetated } \\
\text { Terrain } \\
\text { (cm) }\end{array}$ & $\begin{array}{c}\text { Non- } \\
\text { Vegetated } \\
\text { Vertical } \\
\text { Accuracy } \\
\text { (NVA) } \\
\text { at 95\% } \\
\text { Confidence } \\
\text { Level (cm) }\end{array}$ & $\begin{array}{l}\text { Vegetated } \\
\text { Vertical } \\
\text { Accuracy } \\
\text { (VVA) } \\
\text { at } 95^{\text {min }} \\
\text { Percentile } \\
\text { (cm) }\end{array}$ & $\begin{array}{l}\text { Appropriate } \\
\text { Contour } \\
\text { Interval } \\
\text { supported } \\
\text { by the } \\
\text { RMSEz } \\
\text { value }\end{array}$ & $\begin{array}{c}\text { Recommended } \\
\text { Minimum } \\
\text { Nominal Pulse } \\
\text { Density (pts/ } \\
\left.\text { m }^{2}\right) / \text { Maximum } \\
\text { Nominal } \\
\text { Pulse Spacing } \\
\text { (meters) }\end{array}$ \\
\hline 1 & 1.0 & 2.0 & 2.9 & $3 \mathrm{~cm}$ & $\geq 20 / 0.224$ \\
\hline II & 2.5 & 4.9 & 7.4 & $7.5 \mathrm{~cm}$ & $16 / 0.250$ \\
\hline III & 5.0 & 9.8 & 14.7 & $15 \mathrm{~cm}\left(\sim 6^{\prime \prime}\right)$ & $8 / 0.354$ \\
\hline IV & 10.0 & 19.6 & 29.4 & $30 \mathrm{~cm}\left(\sim 1^{\prime}\right)$ & $2 / 0.707$ \\
\hline V & 12.5 & 24.5 & 36.8 & $37.5 \mathrm{~cm}$ & $1 / 1.000$ \\
\hline VI & 20.0 & 39.2 & 58.8 & $60 \mathrm{~cm}\left(\sim 2^{\prime}\right)$ & $0.5 / 1.414$ \\
\hline VII & 33.3 & 65.3 & 98.0 & 1-meter & $0.25 / 2.000$ \\
\hline VIII & 66.7 & 130.7 & 196.0 & 2-meter & $0.1 / 3.162$ \\
\hline IX & 100.0 & 196.0 & 294.0 & 3-meter & $0.05 / 4.472$ \\
\hline $\mathrm{x}$ & 333.3 & 653.3 & 980.0 & 10-meter & $0.01 / 10.000$ \\
\hline
\end{tabular}

Gambar 8. Akurasi Vertikal ASPRS

(Sumber : ASPRS, 2011)

Dari tabel tersebut, kelas yang sesuai adalah kelas IX untuk data skala 1:10.000 sehingga RMSE maksimumnya adalah 100 $\mathrm{cm}$ atau 1 meter untuk area tanpa vegetasi. Dari uji tersebut dapat disimpulkan bahwa untuk analisa ketelitian DEM yang dibuat dari metode TIN, IDW, dan Kriging menunjukkan nilai RMSE seperti pada grafik berikut.

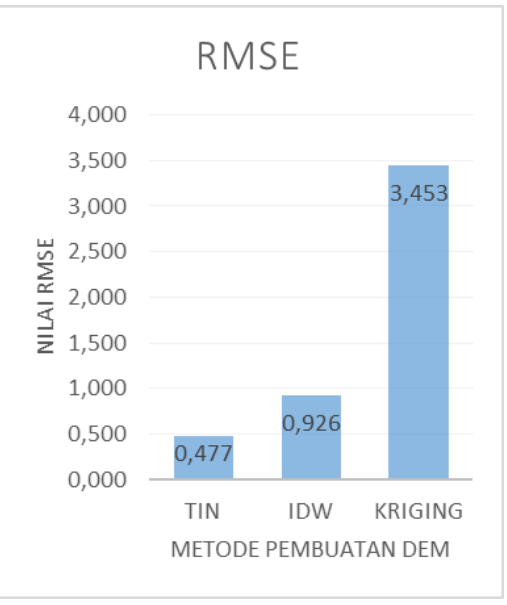

Gambar 9. Perbandingan nilai RMSE dalam grafik

Nilai yang memenuhi syarat standar akurasi vertikal ASPRS yang kurang dari 1 meter terdapat pada metode TIN dan IDW.

\section{KESIMPULAN/RINGKASAN}

Dari hasil pembuatan DEM didapatkan bahwa elevasi terkecil terdapat pada metode TIN yaitu sebesar 58,674 diikuti oleh hasil dari metode IDW sebesar 58,679 dan metode Kriging sebesar 59,364 sedangkan elevasi terbesar terdapat pada hasil dari metode TIN sebesar 107, 638 diikuti metode IDW sebesar 107,513 dan metode Kriging yaitu 99,910. Hasil perhitungan RMSE menunjukkan bahwa nilai dari TIN menunjukkan hasil terkecil yaitu sebesar 0,477 diikuti oleh metode IDW sebesar 0,926 dan metode Kriging 3,453. Dari hasil tersebut nilai yang memenuhi standar perhitungan RMSE adalah TIN dan IDW karena kurang dari sama dengan 1 meter sesuai standar RMSE dari ASPRS. Dari hasil ini dapat disimpulkan bahwa pembuatan DEM paling baik adalah menggunakan metode TIN karena memiliki RMSE terkecil dibandingkan lainnya saat diuji dengan menggunakan elevasi DEM dari data TerraSAR-X.

\section{UCAPAN TERIMA KASIH}

Terima kasih penulis ucapkan kepada Badan Informasi Spasial yang telah menyediakan data hibah foto udara stereo Kecamatan Tegineneg, Kabupaten Pesawaran, Lampung, serta data DEM TerraSAR-X dari Provinsi Lampung.

\section{DAFTAR PUSTAKA}

[1] A. Setianto, T.Triandini, Comparison of Kriging and Inverse Distance Weighted (IDW) Interpolation Methods in Lineament Extraction and Analysis. Journal SE Asian Application Geology. Vol. 5(1) Hal. 21-29. (2013).

[2] ASPRS (American Society of Photogrammetry and Remote Sensing). (2011). ASPRS Accuracy Standards for Digital Geospatial Data.

[3] B. Trisakti, "Pengembangan Metode Ekstraksi DEM (Digital Elevation Model) dari Data ALOS PRISM". LAPAN. (2010).

[4] Badan Informasi Geospasial, Petunjuk Pelaksanaan Tahapan Stereoplotting. Pusat Pemetaan Rupabumi dan Toponim. (2015)

[5] C. Childs, Interpolating Surfaces in ArcGIS Spatial Analyst. ArcUser. ESRI Education Center.(2004).

[6] Chang, K.T. (2008). Introduction to Geographic Information System. Singapura : McGraw Hill.

[7] Li, J. dan Heap, D. (2008). A Review of Spatial Interpolation Methods for Environmental Scientist. Geoscience Australia. Record 2008/23, 137 pp. 
[8] Paul R. Wolf, Bon .A. DeWitt, Elements of Photogrammetry with Application in GIS. McGraw-Hill Higher Education. $3^{\text {rd }}$ Edition. (2000)

[9] USGS, Digital Elevation Model (DEM) Creation and Analysis. Science Education Lesson. (2010) 